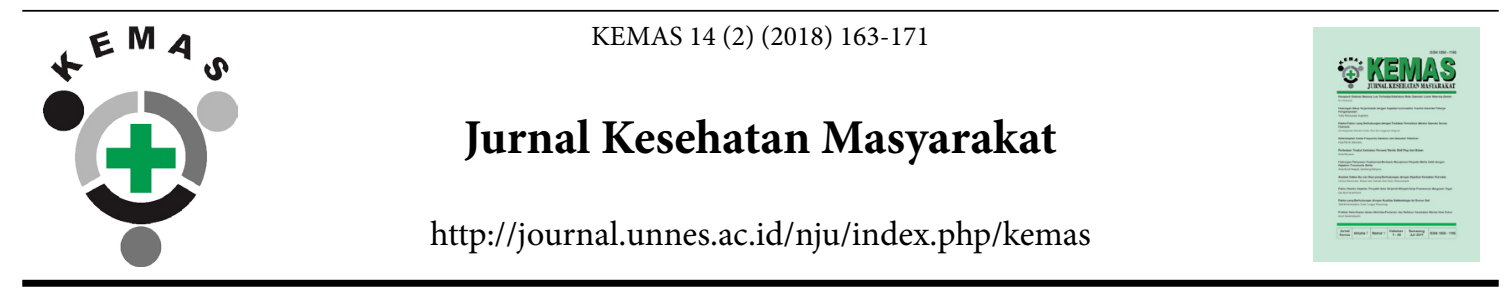

\title{
Knowledge and Implementation of Integrated Management of Childhood Illness at East Kalimantan
}

\author{
Fatma Zulaikha ${ }^{\boxplus}$, Rina Triasih ${ }^{2}$, Purwanta ${ }^{3}$ \\ ${ }^{1}$ Nursing Study Program, Universitas Muhammadiyah Kalimantan Timur \\ ${ }^{2}$ Department of Pediatrics, Faculty of Medicine, Public Health, and Nursing, Universitas Gadjah Mada \\ ${ }^{3}$ Master of Nursing, Faculty of Medicine, Public Health, and Nursing, Universitas Gadjah Mada
}

\section{Article Info \\ Article History: Submitted March 2018 \\ Accepted March 2018 \\ Published November 2018 \\ Keywords: \\ IMCI, cough, \\ knowledge, health worker \\ DOI \\ https://doi.org/10.15294/ \\ kemas.v14i2.13707}

\begin{abstract}
Pneumonia is the most common cause of morbidity and mortality among young children worldwide. Integrated Management of Childhood Illness (IMCI) is a procedural form in the care of childhood illness which aims to minimize morbidity and mortality rate in children, including pneumonia. This was a cross sectional study at Samarinda and Kutai Kartanegara community health center from July to October 2015. The health workers' knowledge was assessed through questionnaire. The quality of IMCI implementation was evaluated through direct observation in primary health care. A total of 46 health workers were involved in this study. Observation of IMCI implementation quality was conducted in 104 children. The majority of respondents (73.9) had sufficient knowledge; however, in terms of direct implementation on the field, most of the respondents (87\%) were included in incompetent category. It can be concluded that level of knowledge was related to implementation of cough IMCI in community health center, but the correlation was weak.
\end{abstract}

\section{Introduction}

Pneumonia is a pulmonary infection which is the main cause of mortality in children under 5 years old (Choiriyah and Anggraini, 2015). In 2013, the prevalence of pneumonia in children under 5 years old in Indonesia reached $4.5 \%$. In Samarinda, the number of pneumonia case was 2.535, while in Kukar, the number was 433 cases. In 2012, the coverage of children under 5 years old care reached 54.170 (54.9\%) while in Kukar, the coverage was 46.461 $(82.5 \%)$. The number of community health center in Samarinda was 24, while the number in Kukar was 27.

In order to reduce mortality rate due to pneumonia among children under 5 years old, a preventive effort is performed through Integrated Management of Childhood Illness (IMCI). IMCI is a procedure to care for children with disease which includes promotive, preventive, and curative measures for diseases which cause death among children under 5 years old (Rohayati et al., 2015).

In IMCI, pneumonia is included in cough or dyspnea classification. Cough or dyspnea classification consists of non pneumonia cough, pneumonia, and severe pneumonia or very severe disease (Silviana et al., 2015). According to IMCI, the management of cough consists of 5 steps, namely assessment, classification, prompt treatment, medication, and counseling for the mother. The benefit of IMCI implementation 
is reducing children under 5 year old mortality rate and increase the quality of low cost healthcare. This is in accordance with a study by Osterholt et al, (2009) which found that implementation of IMCI could increase the quality of care. Rakha et al., (2014) stated that the benefit of IMCI is to reduce mortality rate among children under 5 years old to $6.3 \%$.

According to Kiplagat et al., (2014), implemetation of IMCI was influenced by lack of trained healthcare personnel, insufficient service time, lack of supervision from office of health, and knowledge and attitude of healthcare personnels in implementing IMCI after training. Meanwhile, according to Rohayati et al., (2015), implementation of IMCI was influenced by attitude, adequate facility, and motivation of healthcare personnel in implementing IMCI.

\section{Methods}

This was a quantitative descriptive study using cross sectional technique which was conducted from July to October 2015 in every community health centers that implemented IMCI program in Samarinda City (11 community health centers) and 4 community health centers in Kutai Kartanegera Regency, East Kalimantan. Forty six healthcare personnels from 15 community health centers were involved in this study. This study involved medical doctors, nurses, and midwives in Pediatrics Clinic as respondents. The sampling method was purposive sampling method. The inclusion criteria were executioner of IMCI program in community health center and agreed to become respondent.

The data were collected in community health center for 2-3 days. The time of data collection were suited according to previous schedule commitment with the respondents. Because of the involvement of healthcare personnel as respondents, ethical clearance was submitted to Ethical Committee of Faculty of Medicine, Universitas Gadjah Mada. The researcher acquired ethical clearance before the commencement of the study with ethical ethical clearance number KE-FK/836/EC/2015. Respondents were given informed consent before the study and the identities were made to remain confidential.

The instrument were questionnaire and observation sheet. The questionnaire regarding knowledge level was made by researcher while the observation sheet was modified from Guideline of Acute Respiratory Tract Infection from the Ministry of Health. The questionnaire consisted of 12 question items with the value of true answer equal to 1 and wrong answer equal to 0 . In this study, we used observation sheet regarding documentation and implementation of cough management according to IMCI.

In obervation sheet of documentation, the researcher studied the presence of children under 5 years old visits, the number of incidence of cough and acute respiratory tract infection, implementation of IMCI, reporting of IMCI, availability of IMCI forms, and follow up of IMCI training. In observation sheet, the researcher studied 5 steps of cough management according to IMCI which consisted of assesment, classification, appropriate action, drug administration according to indication, and counseling of the mother. The instrument used scoring with value of 2 when the step was performed completely, value of 1 when the step was partially performed, and 0 when the step was not performed.

Validation test of the questionnaire was conducted towards 32 respondents from 11 community health center in Samarinda City in June 2015. Spearman Rank Test was used as statistical test of validity and Cronbach Alpha test was used as statistical test of reliability. Twelve from 20 items of the questionnaire were found to be valid and reliable.

The data on level of knowledge was collected using closed questionnaire. Questionnaire was filled and collected after service hours in order not to disturb service hours. The questionnaire was answered by the respondents themselves and the limit of collection time was set at 12.00 WIB. The collection of data regarding implementation was conducted using observation sheet and interview. The interview was performed toward the respondents after the end of working hours. The information which were looked for were number of daily children visit, implementation of IMCI, utilization and availability of IMCI forms, follow up of IMCI training, and the number children in which the IMCI assesment were performed. The result of the interviews 
were transcribed into observation sheet of documentation of IMCI implementation.

The observation of IMCI implementation was conducted by the researcher through direct observation of steps in management of cough which were performed by the respondents when they care for patients with cough according to IMCI approach. However, the respondents did not have knowledge regarding the observation previously. This was conducted in order to reduce bias. Observation assesment was conducted using observation sheet. The asesment was conducted according to the steps of cough management according to IMCI, namely assesment, classification, action, medication, and counseling.

The questionnaires were filled after the respondents finished their IMCI approach. The researcher filled the observation sheet without the knowledge of the respondents. In addition, the researcher also validated observation results by examining patient's medical record and directly asked the respondents. Observation in every community health centers in Samarinda City were performed for 2-3 days, while observation in community health centers in Kutai Kartanegara Regency were performed for 1-2 days. For each respondents, the observation was performed for at least 3 children. However, this would be adjusted to the condition of each centers, because the researcher could not control the children's visit. The total number of children with cough in this study was 104 children.

The demographic data consisted of age, gender, level of education, type of profession, length of work, attendance of IMCI training, and source of information. The questionnaires were tested for their validity and reliability first. Chi square test was used to analyse the relationship between level of knowledge and implementation of cough management according to IMCI.

\section{Results and Discussion}

From 46 healthcare personnels, most were female $(95.7 \%)$, aged less than 35 years old $(54.3 \%)$, worked as midwife (58.7\%), had diploma as highest education level (69.5\%), has been working for less than 5 years $(58.7 \%)$, and never attended IMCI training (54.3\%). For questions about information regarding
IMCI, the majority of the respondents (21 personnel/45.6\%) answered that they acquire information regarding IMCI from training.

This study also involved 104 children with cough symptoms who were visited community health center and were treated using IMCI approach. IMCI approach was conducted to children aged 0-59 months. The average age of the children was 22.6 months, the most common diagnosis was non pneumonia cough (93 out of 104 children), and the majority were female.

The majority of the respondent had sufficient level of knowledge (34/73.9\%), however, most respondents were incompetent in terms of implementation (87\%). The median value of level knowledge was 11 while the mean value for implementation was 4 . The result of the analysis showed that there was no relationship between level of knowledge on cough IMCI and competence of healhcare personnel in implementing cough IMCI $(\mathrm{p}=0.032)$ with OR value of 0.82 (95\% CI $0.71-0.96)$ which meant that healthcare personnel with sufficient level of knowledge had 1 times larger chance to implement IMCI competently.

The majority of the respondents conduct implementation in incompetent category, especially in assesment step (91.3\%), classification step (56.5\%), and action step (54.3\%). Meanwhile, in medication and counseling steps, around half of the respondents conduct those steps competently.

From the result of cross test between level of knowledge and implementation, it was found that most of the respondents $(60.86 \%)$ had good level of knowledge and perform incompetent implementation, 12 respondents (26.08\%) had low level of knowledge and perform incompetent implementation, while 6 respondents (13.04\%) had good level of knowledge and perform competent implementation.

This study also conducted analysis of correlation between characteristics and level of knowledge and implementation using Chi Square test. It was found that IMCI training attendance factor had the most significant influence on level of knowledge, while age, length of work, and IMCI training attendance had the most significant influence on 
implementation.

The results of bivariate analysis between respondent's characteristics and level of knowledge regarding cough IMCI found no significant relationship ( $>0.05)$. Respondents with age less than 35 years old had 1 times higher probability to possess good level of knowledge regarding cough IMCI (OR 1.27, 95\% CI 0.33-4.74).

There was no relationship between type of profession and respondent's level of knowledge regarding cough IMCI $(\mathrm{p}>0.05)$. This meant that type of profession did not determine respondent's level of knowledge. Nurse and midwife had 1 times higher probability to possess good level of knowledge compared to medical doctor.

Length of work did not have significant relationship with level of knowledge $(\mathrm{p}=0.74)$. Respondent with more than 5 years work experience had 1 times smaller probability to posses good level of knowledge compared to respondent with less than 5 years work experience. There was no significant relationship between gender and level of knowledge $(\mathrm{p}=0.46)$. Female respondent had 3 times higher probability to possess good level of knowledge compared to male respondent (OR 3.00, 95\% CI 0.17-52.1).

Education level did not have significant relationship with respondent's level of knowledge regarding cough IMCI $(\mathrm{p}>0.05)$. Respondents with diploma or undergraduate degrees had similar probability to possess good level of knowledge regarding cough IMCI.

Respondents who have not attend IMCI training had low probability to possess good level of knowledge compared to respondents who have attend IMCI training, however the relationship was not statistically significant $(p>0.05)$. Source of information also did not have significant relationship with level of knowledge regarding cough IMCI $(\mathrm{p}>0.05)$. Respondents who used book, education, and internet had three times higher probability to possess good level of knowledge compared to respondents who only acquired IMCI information from training.

The results of Fisher's exact test between respondent's age and implementation found $\mathrm{p}$-value of $0.46, \mathrm{OR}=1.81$ (95\% CI $0.3-11.03)$ which meant that there was no relationship between respondent's age and implementation of cough IMCI. The OR value showed that respondent with age less than 35 years old had 2 times higher probability to implement IMCI competently.

Type of profession and implementation of cough management did not have significant relationship $(\mathrm{p}=0.52)$ which meant that type of profession did not determine whether the respondents were competent or incompetent in implementing management of cough according to IMCI. In other words, all type of profession had similar probability to implement cough management competently $(\mathrm{OR}=0.56,95 \% \mathrm{CI}$ 0.05-6.02)

Respondents with less than 5 years work experience had 3 times higher probability to perform competent implementation compared to respondents wit more than 5 years work experience, however, the relationship was not statisticallysignificant $(\mathrm{p}>0.05)$. The relationship between gender and implementation of cough management according to IMCI did not show statistically significant relationship $(\mathrm{p}=0.25)$. Men and women had similar probability to perform IMCI management competently (OR $=0.13,95 \% \mathrm{CI}=0.07-2.39$ ).

There was no significant relationship between respondent's education level and implementation of cough management according to IMCI $(\mathrm{p}>0.05)$. Respondents with diploma education had lower probability to implement competently compared to undergraduate respondents. Respondents who attend IMCI training had 1 times higher probability to implement competently. However, the relationship between respondent's attendance in IMCI training implementation of cough management according to IMCI was not statistically significant ( $p>0.05)$.

Respondents who use book, internet, and education had similar probability with respondents who use IMCI training as source of information $(\mathrm{OR}<1)$, however, the relationship was not statistically significant $(p>0.05)$.

Bivariate analysis found 4 variables with p-value $<0.25$, namely level of education, length of work, gender, and source of information. Those variables were tested using logistic regression test. Multivariate analysis found the 
strongest relationship was level of knowledge $(\mathrm{OR}=3.355)$ and the weakest relationship was gender $(\mathrm{OR}=0.353)$. This meant thar respondents with undergraduate degree had 3 times higher probability to perform competent implementation. Respondents with less than 5 years work experience had 2 times higher probabiity to perform competent implementation. The result of this study showed that all variables did not have significant relationship with implementation of cough management according to IMCI.

Thirty four respondents (73.9\%) had good level of knowledge regarding cough IMCI. This was in accordance with a study by Joshi, P. Vatsa (2014) who reported that most of the nurses (51.4\%) had good level of knowledge regarding IMCI. A study by Kalu et al., (2016) also stated that most of the healthcare personnel had good level of knowledge regarding IMCI and able to implement IMCI competently.

Most of the respondent had sufficient knowledge on cough IMCI (73.9\%), this was influenced by respondent's education level and age because most of the respondents had diploma education (69.5\%) and age less that 35 years old (54.3\%) which support them to have good level of knowledge. A different result was found by Joshi, P. Vatsa (2014) who stated that healthcare personnel's knowledge regarding IMCI was not influenced by gender and length of work.

Gender and type of profession did not have influence on healthcare personnel's level of knowledge regarding IMCI because knowledge could be acquired from several sources, training and education. More information sources on IMCI would help increase the knowledge and influence the perception of healthcare personnels to receive new ideas.

Rahman (2014) also stated that education level also affected level of knowledge. Higher education level would support respondent to possess sufficient level of knowledge. Level of knowledge was also a factor that determine healthcare personnels' skills in implementing IMCI. Nislawaty (2015) stated that there was a significant relationship between level of knowledge and work experience with implementation of IMCI.

Healthcare personnel's attendance in
IMCI training also affect their knowledge regarding IMCI. This was in accordance with a study by Rakha et al., (2014) which stated that healthcare personnel who attend IMCI training had sufficient level of knowledge compared to personnel who did not attend IMCI training, particularly in medication and home care counseling aspects.

Forty healthcare personnels (87\%) performed cough management implementation incompetently. This was caused by IMCI training which is not routinely held each year, lack of IMCI medication and supporting equipment availability, lack of repondent's awareness and motivation to use IMCI supporting equipments (IMCI form and diagram book) when implementing IMCI approach. Therefore, the quality of IMCI implementation and reporting were not optimal.

Implementation of IMCI in community health centers of Samarinda City and Kutai Kartanegara Regency did not run well because of multiple factors, particularly a long duration of IMCI implementation from assessment step to counseling step which took 10-15 minutes per patient and incomplete IMCI equipment and facilities in each community health centers which affect IMCI implementation.

Most of the respondents did not implement IMCI according to IMCI diagram book. This finding was based on observation which found that IMCI diagram book was not used during IMCI implementation which could produce inappropriate assesment, classification, medication, and action and in turn resulted in inappropriate counseling. Those events affected the quality of IMCI in ill children.

The result of this study was different from previous study by Hidayati and Wahyono (2011) which found implementation by healthcare personnel to be good (53\%). The results showed that healthcare personnels were able to perform assesment, classification, determine action, and provide medication, counsel the mother, and provide follow up action properly, therefore reducing prevalence of pneumonia in children under 5 years old.

IMCI training could not be attended by all respondents in Pediatrics Clinic because Health Agency only provided opportunity for medical doctors and midwives as program 
caretaker to attend IMCI training. In addition, the training was not routinely held each year and there was no routine follow up 6 months after training which made IMCI implementation in Samarinda City and Kutai Kartanegara Regency were included in incompetent category.

Respondent's attendance in IMCI training could increase knowledge, ability, and skills, therefore IMCI implementation in community health center could be better. Kiplagat et al., (2014), Mayhew, et al.,(2015), Steinhardt et al., (2015) also reported that healthcare personnels who received IMCI training could implement IMCI better.

A study by Rahman (2014) found a significant relationship between healthcare personnel's knowledge and training with healthcare personnel's compliance in implementing pneumonia management according to IMCI. Healthcare personnels who attended training had 2 times higher compliance compared to healthcare personnel who did not attend the training.

A different result was found by Harerimana et al., (2014) who found that IMCI training did not have significant influence on healthcare personnel's ability in determining classification and providing IMCI medication. Nislawaty (2015) also stated that there was no correlation between IMCI training and good IMCI implementation.

Based on studies by Titaley et al., (2014) and Mayhew et al., (2015), non-routine follow up, non-routine IMCI training, lack of IMCI forms, equipment, and facilities availlability, and lack of medical doctors were also factors which inhibit IMCI implementation. IMCI training attendance and routine follow up had influence on increase of quality of care. Therefore, if healthcare personnel did not receive opportunity to attend routine IMCI training and after training follow up, it would cause decrease in healthcare quality (Bjornstad et al., 2014).

Similar result with Mayhew et al., (2015), Sarganas et al., (2012) also found inhibiting factor of IMCI implementation, namely lack of trained human resources, inadequate service time, lack of government support regarding IMCI training towards respondents, attitude of healthcare personnel towards IMCI program, lack of support from patient's family, and lack of follow up after IMCI training. A study by Hidayati and Wahyono (2011) also found that IMCI supporting equipment had influence on prevalence of pneumonia in children under 5 years old.

Steinhardt et al., (2015) stated that routine follow up was advised in order to increase the quality of IMCI implementation, particularly in community health centers which had old age respondents, therefore, routine follow up could improve attitude mistake in management implementation by respondents with long work experience and old age. Steinhardt et al., (2015) also reported that non routine follow up also affected respondents' ability in performing history taking and disease classification, especially in young infant with severe infection.

According to Adekanye and Odetola (2014), IMCI could be implemented properly when it is supported by numerous factors, namely support from health facility institution, cooperative attitude of nurses, family support, and routine IMCI training for healthcare personnels. Therefore, the presence of good implementation could increase nurse's capability in implementing health care, especially for pediatric patients.

Meanwhile, according to Rohayati et al., (2015), beside IMCI support facility factors, IMCI implementation was also influenced by health personnel's motivation and self awareness in performing IMCI implementation for ill child in community health center. In similar results with Rohayati et al., (2015) also stated that IMCI implementation was affected by healthcare personnel's work motivation and ability in implementing IMCI care. This was different with a study by Pradhan et al., (2012) which found supporting factor of IMCI implementation, namely respondent's knowledge and perception towards IMCI program. Knowledge regarding IMCI could be acquired from education, through diagram book which was available at community health center, through experience which was acquired during their job, and through IMCI training.

Steinhardt et al., (2015) stated that the more experience which was possessed by the respondents caused change of attitude in respondents which caused them to carry 
out numerous mistakes during their work. Beside that, presence of experience made the respondents did not use IMCI diagram book as basis for treatment. Steinhardt also reported that respondents with longer work experience had low ability in terms of treatment aspect, namely around $15-88 \%$.

In similar finding with Steinhardt et al., (2015) also stated that there was no significant relationship between health care personnel's age, work experience, level of education, and level of knowledge of IMCI program executioner and prevalence of pneumonia in children under 5 years old. Meanwhile, according to Hidayati and Wahyono (2011), pneumonia case finding in children under 5 years old could be affected by availability of IMCI supporting facility in community health center.

A study by Prabawa and Azinar (2017) stated that prevalence of pneumonia in children under 5 years old could be influenced by midwive's knowledge regarding pneumonia, multiple task which had to be carried out, duration of program possession, and support from head of community health center towards pneumonia case finding in children under 5 years old. Meanwhile, midwive's age, attitude, IMCI facility availability and work partner support in community health center did not have significant influence towards prevalence of pneumonia in children under 5 years old (Shewade \& Anggarwal, 2013).

The majority of respondents implemented IMCI in incompetent category, particularly in the assesment step (92.3\%), classification (56.5\%), and action (54.3\%), while in medication and counseling steps, half of the respondents (50\%) performed those steps competently. This was in accordance with a study by Bjornstad et al., (2014) which found that only few respondents could perform proper pneumonia diagnosis $(30 \%)$, proper action $(<25 \%)$, and did not give proper referral for children with severe pneumonia (40.8\%).

In similar finding with Bjornstad, Tuhebwe et al., (2014) also found that majority of healthcare personnels could not mention pneumonia danger signs. In medication steps, majority of healthcare personnel gave unadvised beverage to children with pneumonia and only few of the respondents (31.7\%) which gave proper antibiotics.

A study by Johansson et al., (2016) also found similar findings with Tuhebwe that in medication step, few of children with pneumonia (28\%) did not receive proper antibiotics. On the contrary, most of children without pneumonia (59\%) received unnecessary antibiotics. A study by Nurhayati et al., (2010) stated that proper and good IMCI implementation could increase child patient's cure rate up to 4 times higher.

\section{Conclusions}

Healthcare personnels had sufficient level of knowledge regarding IMCI (73.9\%) but they performed cough management according to IMCI in incompetent category (87\%). Quality of cough management according to IMCI did not have significant relationship with age, profession, length of work, gender, source of information, and level of education. IMCI training attendance had correlation with quality of cough management implementation according to IMCI. Better level of knowledge would result in better implementation of cough management according to IMCI, however, the correlation between two variables was weak.

\section{References}

Adekanye, O.E., \& Odetola, T.D., 2014. Awareness and Implementation of Integrated Management of Childhood Illness (IMCI) Among Nurses in Paediatric Settings of Selected Hospitals in Ibadan, Nigeria. IOSR Journal of Nursing and Health Science, 3(5), pp. 29-34.

Bjornstad, E., Preidis, G.A., Lufesi, N., Olson, D., Kamthunzi, P., Hosseinipour, M.C., \& McCollum, E.D., 2014. Determining the Quality of IMCI Pneumonia Care in Malawian Children. Paediatrics and International Child Health, 34(1), pp.30-36.

Choiriyah, S., \& Anggraini, D.N., 2015. Evaluasi Input Sistem Surveilans Penemuan Penderita Pneumonia Balita di Puskesmas. Unnes Journal of Public Health, 4(4), pp.136-145.

Harerimana, J.M., Nyirazinyoye, L., Ahoranayezu, J.B., Bikorimana, F., Bethany, L.H.G., Muldoon, K.A., Mills, E.J., \& Ntaganira, J., 2014. Effect of Shortened Integrated Management of Childhood Illness training on Classification and Treatment of UnderFive Children Seeking Care in Rwanda. Risk Management and Healthcare Policy, 7, pp.99104.

Hidayati, A.N., \& Wahyono, B., 2011. Pelayanan 
Puskesmas Berbasis Manajemen Terpadu Balita Sakit Dengan Kejadian Pneumonia Balita. Kemas, 7(1), pp.35-40.

Johansson, E.W., Selling, K.E., Nsona, H., Mappin, B., Gething, P.W., Petzold, M., Peterson, S.S., \& Hildenwall, H., 2016. Integrated Paediatric Fever Management and Antibiotic Overtreatment in Malawi Health Facilities: Data Mining a National Facility Census. Malaria Journal, 15(396), pp.1-12.

Joshi, P., \& Vatsa, M., 2014. Knowledge, Attitude and Performanceof IMNCI Trained Nursing Personnel: An Evaluative Survey. Indian J.Pediatr, 81(5), pp.450-454.

Kalu, N., Lufesi, N., Havens, D., \& Mortimer, K., 2016. Implementation of World Health Organization Integrated Management of Childhood Illnesses (IMCI) Guidelines for the Assessment of Pneumonia in the Under 5s in Rural Malawi. PLoS ONE, 11(5), pp.1-7.

Kiplagat, A., Musto, R., Mwizamholya, D., \& Morona, D., 2014. Factors Influencing the Implementation of Integrated Management of Childhood Illness (IMCI) by Healthcare Workers at Public Health Centers \& Dispensaries in Mwanza, Tanzania. BMC Public Health, 14(277), pp.1-10.

Mayhew, M., Ickx, P. Newbrander, W., Stanekzei, H., \& Alawi, S., 2015. Long and Short Integrated Management of Childhood Illness (IMCI) Training Courses in Afghanistan : A Cross Sectional Cohort Comparison of Post Course Knowledge and Performance. Int J Health Policy Manag, 4(3), pp.143-152.

Nislawaty., 2015. Faktor- faktor yang Berhubungan dengan Pelaksanaan Manajemen Terpadu Balita Sakit (MTBS) di Wilayah kerja Puskesmas Rimba Melintang Kabupaten Rokan Hilir Tahun 2014. Doppler, 6, pp.2837.

Nurhayati, D., \& Wibowo, T., 2010. Evaluasi Pelayanan Manajemen Terpadu Balita Sakit Terhadap Kesembuhan Pneumonia Pada Anak Balita. Berita Kedokteran Masyarakat, 26 (4), pp.211-217.

Osterholt, D.M., Onikpo, F., Lama, M., Deming, M.S., \& Rowe, A., 2009. Human Resources for Health Improving Pneumonia Case Management in Benin: a Randomized Trial of a Multi Faceted Intervention to Support Health Worker Guidelines. BMC Public Health, 7(7), pp. 1-13.

Prabawa, H.E., \& Azinar, M., 2017. Faktorfaktor yang Berhubungan dengan Praktik Penemuan Pneumonia Balita oleh Bidan. Unnes Journal of Public Health, 6(3), pp.148-
154.

Pradhan, N.A., Rizvi, N., \& Sami, N.G.X., 2012. Insight into Implementation of FacilityBased Integrated Management of Childhood Illness Strategy in a Rural District of Sindh, Pakistan. Global Health Action, 6, pp.1-15.

Rahman, A., 2014. Evaluasi Kepatuhan Petugas dalam Tatalaksana Pneumonia di Kabupaten Tolitoli. Promotif, 3, pp. 101-109.

Rakha, M.A., Abdelmoneim, A.N.M., Farhoud, S., Pièche, S., Cousens, S., Daelmans, B., \& Bahl, R., 2014. Does Implementation of the IMCI Strategy Have an Impact on Child Mortality? A Retrospective Analysis of Routine Data from Egypt. BMJ Open, 2013(3), pp.1-10.

Rohayati, S., \& Purwati., 2015. Analisis Faktor Pelaksanaan Manajemen Terpadu Balita Sakit (MTBS) di Puskesmas. Jurnal Keperawatan, 11, pp.112-117.

Sarganas, G., Scherpbier, R., \& Gericke, C., 2012. Constraint, Synergies and Avenues for Scaling up Breastfeeding, Antibiotics for Pneumonia and IMCI Interventions in The Cusco Region Peru. F1000RESEARCH, 1(60), pp.1-14.

Shewade H.D., \& Anggarwal, A.K., 2013. Integrated Management of Neonatal and Childhood Illness (IMNCI): Skill Assessment of Health and Integrated Child Development Scheme (ICDS) Workers to Classify Sick Under Five. The Indian Journal of Pediatrics, 80(6), pp.448-454.

Silviana, P., Hestiningsih, R., \& Wuryanto, M.A., 2015. Hubungan Karakteristik Individu Dan Perilaku pada Petugas Manajemen Terpadu Balita Sakit (MTBS) Dengan Cakupan Penemuan Pneumonia di Puskesmas Kabupaten Kebumen. Jurnal Kesehatan Masyarakat, 3(1), pp.171-180.

Steinhardt, L.C., Onikpo, F., Kouamé, J., Piercefield, E., Lama, M., Deming, M.S., \& Rowe, A.K., 2015. Predictors of Health Worker Performance after Integrated Management of Childhood Illness Training in Benin: a Cohort Study. BMC Health Services Research, 15(276), pp.1-11.

Sulastriningsih, K., \& Novita, A. 2016. Pengaruh Kemampuan dan Motivasi Kerja Petugas Kesehatan terhadap Kinerja dalam Penerapan Program Manajemen Terpadu Balita Sakit di Puskesmas Pasar Minggu. Jurnal Akademi Keperawatan Husada karya Jaya, 2(1), pp.3-12.

Titaley, C., Jusril, H., Ariawan, I., Soeharno, N., Setiawan, T., \& Weber, M., 2014. Challenges to the Implementation of the Integrated 
Management of Childhood Illness (IMCI) at Community Health Centres in West Java Province, Indonesia. WHO South-East Asia Journal of Public Health, 3(2), pp.161-170.

Tuhebwe, D., Tumushabe, E., Leontsini, E.,
\& Wanyenze, R.K., 2014. Pneumonia among Children Under Five in Uganda: Symptom Recognition and Actions Taken by Caretakers. African Health Sciences, 14, pp.993-1000. 